\title{
APLIKASI PROGRAM DELPHI SEBAGAI PENGGANTI KALENDER REPRODUKSI UNTUK OPTIMALISASI PRODUKTIVITAS KAMBING ETAWA MENUJU PETERNAKAN MODERN
}

Oleh :

$$
\text { AMAL BAHARIAWAN *) dan UJANG SURYADI **) }
$$

\begin{abstract}
ABSTRAK
Kalender reproduksi merupakan salah satu media informasi yang berfungsi sebagai almanak, berisi penanggalan dan keterangan-keterangan yang dapat digunakan untuk mempercepat penentuan waktu siklus reproduksi seperti: tanggal kawin, tanggal bernak, waktu penyapihan anak, dan masa laktasi. Kalender reproduksi digunakan sebagai pedoman untuk pencatatan kegiatan manajemen pemeliharaan ternak. Kegiatan pencatatan (reccording) manajemen reproduksi masih jarang dilakukan dengan baik dan tersimpan rapi karena dirasakan adanya tambahan pekerjaan yang bersifat non teknis, dan dianggap hanya sebagai penunjang manajemen usaha. Aplikasi program komputer sebagai pengganti kalender reproduksi untuk optimalisasi produkstivitas ternak khususnya Kambing Etawa dapat dibuat atas informasi dasar reproduksi kambing. Kalender reproduksi ini akan lebih aplikatif apabila dibuat dalam bentuk pogram komputer menggunakan Delphi. Tujuan penelitian ini adalah membuat program komputerisasi kalender reproduksi untuk ternak Kambing Etawa, Menstimuli aktivitas petemak supaya lebih terprogram, tepat waktu dan tepat kegiatan dalam pemeliharaan ternaknya, dan Memberikan pedoman bagi peternak kambing dalam memaksimalkan produktifitas ternaknya supaya dapat beranak tiga kali dalam dua tahun. Dari hasil penelitian pembuatan kalender reproduksi kambing Etawa dengan Aplikasi program Delphi dapat disimpulkan bahwa: alender Reproduksi dengan Delphi lebih Aplikatif, ktivitas Petemak lebih terprogram, tepat waktu dan tepat kegiatan dalam pemeliharaan ternaknya, memberikan pedoman bagi peternak kambing dalam memaksimalkan produktifitas ternaknya supaya dapat beranak tiga kali dalam dua tahun. Untuk lebih memaksimalkan fungsi kalender reproduksi ini dan juga lebih menarik maka perlu ditambahkan grafik produksi anak dan susu dalam bentuk grafik.
\end{abstract}

Kata Kunci: Delphi, Kalender, Kambing Etawa, Reproduksi 


\section{PENDAHULUAN}

Kalender reproduksi merupakan salah satu media informasi yang berfungsi sebagai almanak, berisi penanggalan dan keteranganketerangan yang dapat digunakan untuk mempercepat penentuan waktu siklus reproduksi diantaranya tanggal kawin, tanggal bernak, waktu penyapihan anak, dan masa laktasi. Kalender reproduksi digunakan sebagai pedoman untuk pencatatan kegiatan manajemen pemeliharaan ternak. Pencatatan ini penting untuk menunjang kelancaran dan keberhasilan proses produksi, karena pencatatan yang rapi dan akurat dapat dijadikan sumber bahan evaluasi kegiatan yang telah dilakukan dan dapat digunakan sebagai acuan perencanaan untuk kegiatan dimasa akan datang.

Kegiatan pencatatan (reccording) manajemen reproduksi masih jarang dilakukan dengan baik dan tersimpan rapi karena mereka merasakan adanya tambahan pekerjaan yang bersifat non teknis dalam pemeliharaan, dan dianggap hanya sebagai penunjang manajemen usaha. Anggapan bahwa pencatatan sebagai tambahan pekerjaan sebenarnya merupakan ungkapan dari rumitnya sistim pencatatan yang ada sekarang yang masih bersifat manual. Namun demikian diera komputerisasi sekarang ini, rumitnya pencatatan tersebut dapat dipermudah dan disederhanakan dengan dibuatkan aplikasi program komputer (komputerisasi).

Aplikasi program komputer sebagai pengganti kalender reproduksi untuk optimalisasi produkstivitas ternak khususnya Kambing Etawa dapat dibuat atas informasi dasar reproduksi kambing yaitu kambing mampu beranak tiga kali per dua tahun, periode reproduksi (periode persiapan kawin, periode kebuntingan, periode kering kandang, dan periode laktasi) merupakan siklus yang berulang selama ternak tersebut hidup, setiap periode reproduksi memiliki manajemen pemeliharaan dan waktu yang tetap diantaranya tingkat pemberian nutrisi, dan manajemen kesehatan. Atas dasar tersebut di atas kalender reproduksi ini akan lebih aplikatif apabila dibuat dalam bentuk pogram komputer menggunakan Delphi, sehingga dalam penggunaannya pemakai hanya tinggal memasukkan parameter yang diminta oleh tampilan menu program maka untuk proses selanjutnya komputer yang menjalankan sesuai dengan permintaan pengguna.

\section{METODOLOGI}

\section{Tempat dan Waktu Penelitian}

Penelitian ini dilaksanakan di

Laboraturium Komputer Politeknik Negeri Jember dan Lab Ternak Politeknik Negeri Jember. Penelitian dilakukan selama 10 bulan.

\section{Alat dan Bahan}

Alat yang dignakan dalam penelitian adalah seabgai berikut:
a) Program aplikasi Delphi
b) Komputer
c) Kalender putar manual

Kerangkan Pemecahan Masalah

Delphi merupakan salah satu program aplikasi yang dapat dipergunakan untuk penyelesaian masalah diantaranya adalah perhitungan dengan banyak mengggunakan parameter. Berdasarkan parameter yang ada, delphi akan memproses sesuai dengan nalar yang akan dipergunakan untuk penyelesaian masalah tersebut.

Parameter input yang digunakan dalam siklus reproduksi adalah: tanggal bunting, tanggal lahir, tanggal sapih, tanggal persipan kawin, dan tanggal kering kadang. Parameter input tersebut oleh program Delphi akan diproses dengan lamanya waktu setiap para meter input sebagai konstanta yang digunakan untuk dasar pembuatan program. Konstanta yang digunakan yaitu : Masa Persiapan Kawin (MPK) = 1 Bulan; Masa Perkawinan $(\mathrm{MP})=2$ Bulan; Masa Bunting $(\mathrm{MB})$ = 5 bulan; Masa Laktasi (produksi Susu ) (ML) = 6 bulan; Masa Kering Kandang $(\mathrm{MKK})=2$ bulan; Masa Lahir -sapih (MLS) = 3 bulan; dan Masa Pembesaran $(\mathrm{MP})=6$ bulan . 


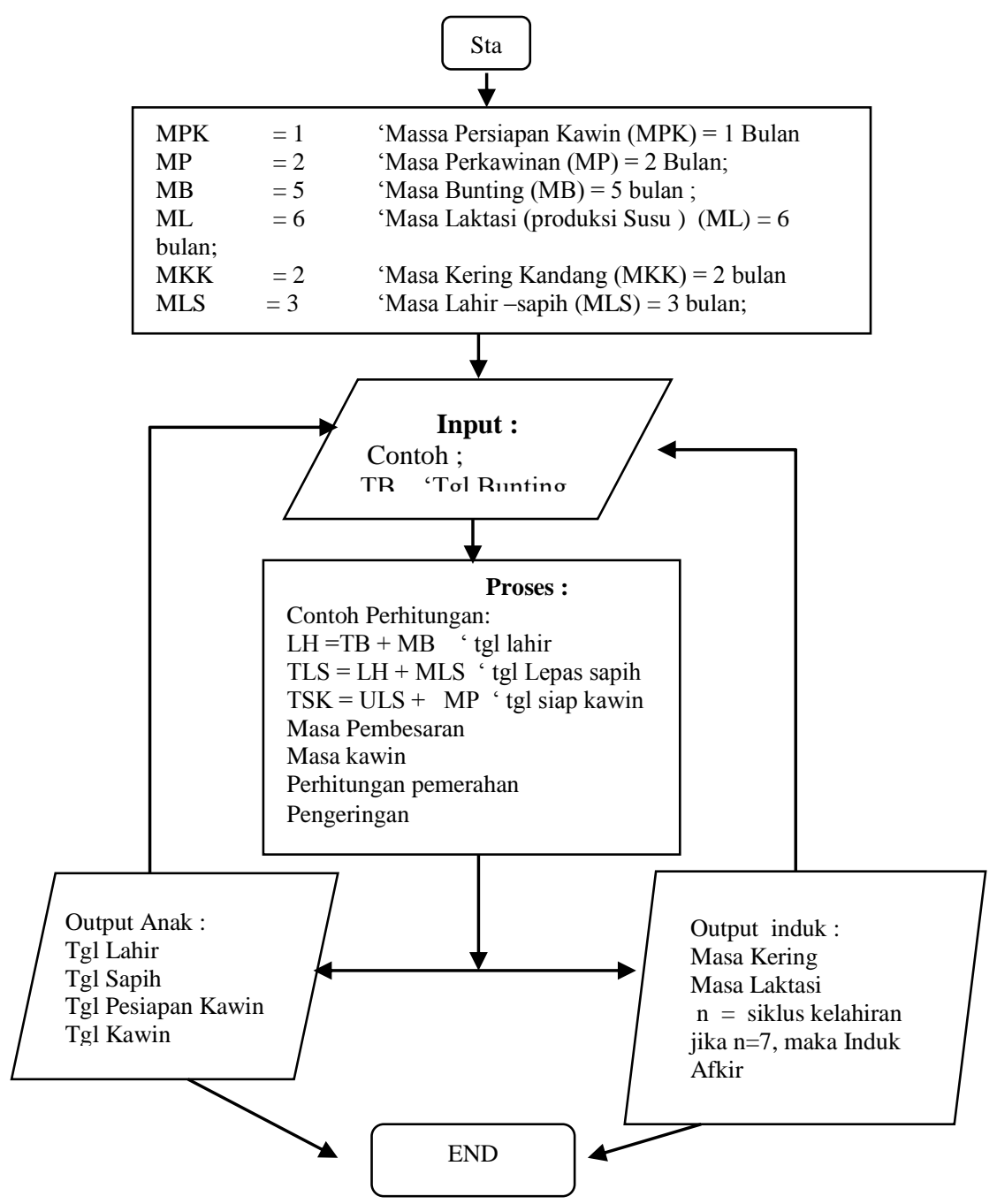

Flow chart Programer Periode Reproduksi Kambing ET

Variabel Penelitian yang Diamati

Variabel penelitian yang diamati dari program ini berbentuk out put hasil proses variabel input yang dilakukan oleh program delphi. Out put yang diharapakan yaitu :

a. Penetapan tanggal lahir, berupa tanggal waktu induk melahirkan dan tanggal anak dilahirkan yang dihitung 5 bulan setelah menunjukkan tanda kebuntingan.

b. Penetapan tanggal sapih, yaitu tanggal anak harus disapih yang dihitung 3 bulan setelah tanggal dilahirkan.

c. Penetapan tanggal pembesaran, yaitu tanggal anak mulai masuk periode pembesaran yang dihitung 6 bulan setelah tanggal penyapihan.

d. Penetapan tanggal kawin, yaitu tanggal dimasukannya kambing induk setelah melahirkan atau kambing dara ke kandang kawin untuk proses perkawinan sampai menunjukan tanda kebuntingan, dihitung 3 bulan setelah melahirkan untuk induk atau 9 bulan dari tanggal lahir bagi kambing dara.

e. Penetapan tanggal kering kadang, yaitu tanggal dihentikannya proses pemerahan susu, dihitung 2 bulan sebelum tanggal 


\section{HASIL DAN PEMBAHASAN}

Kalender reproduksi Kambing Etawa yang dibuat dengan program Delphi menampilkan beberapa Menu Bar yang didalamnya mengandung kotak isian data yang harus diisi secara manual dan ada juga kotak data yang terisi melalui suatu proses perhitungan. Adapun menu utama yang ditampilkan adalah: Index data, Prediksi, Karakteristik, Foto, Laporan, dan Prediksi Kelahiran.

\section{Index Data}

Index data mengandung kotak isian yang harus diisi secara manual melalui papan ketik, dan tidak mengandung suatu proses perhitungan. Data isian harus menggambarkan arti isian dan mempunyai perbedaan yang jelas antar data isian. Hal ini dilakukan untuk mempermudah membaca data pada waktu data laporan dicetak.

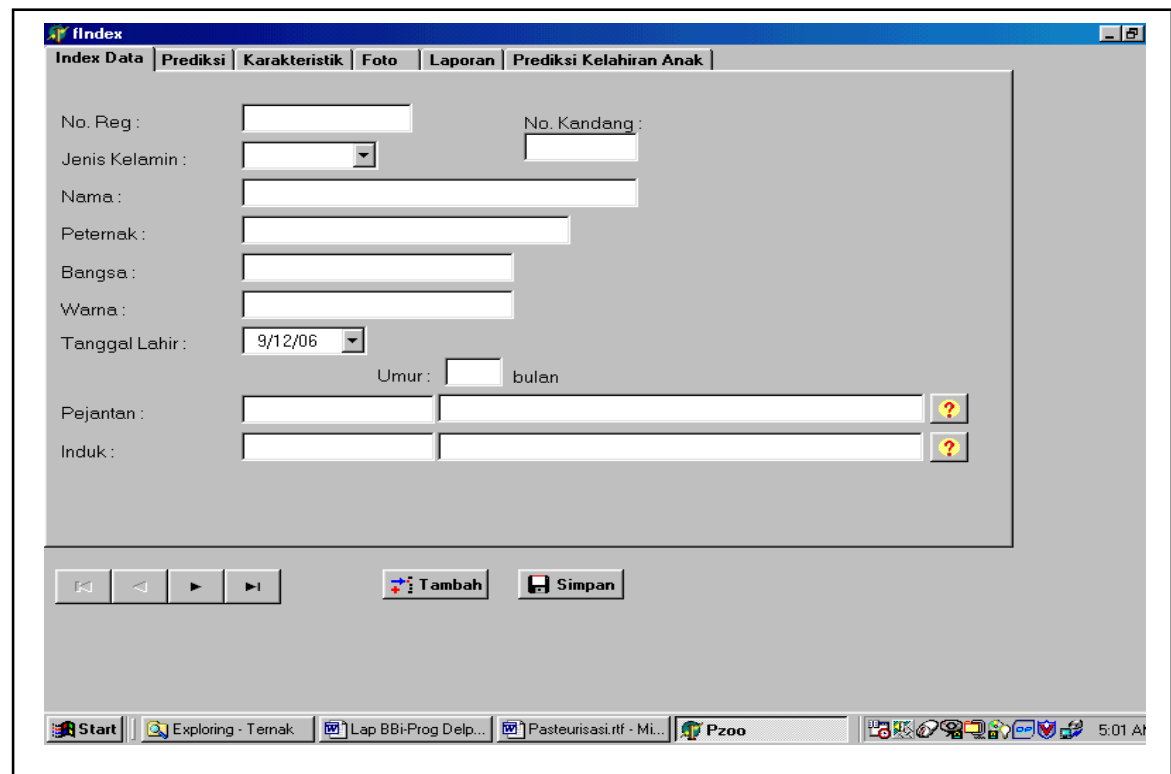

Gambar 1. Tampilan Menu bar Index Data yang belum terisi

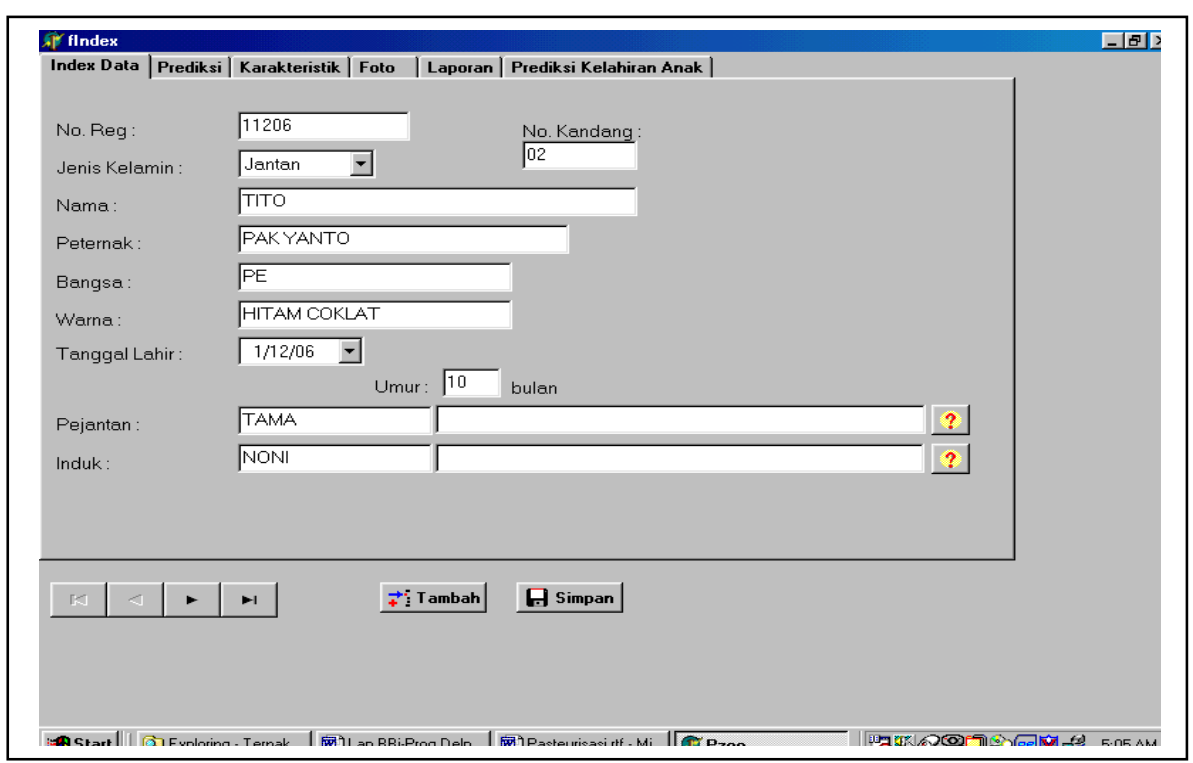


Gambar. 2 Tampilan Menu Bar Index data yang sudah terisi secara manual

\section{Prediksi}

Menu Bar Prediksi ini mengandung hanya satu isian manual yaitu tanggal bunting induk dan dapat memprediksi anak yang lahir seperti: tanggal lahir anak, tanggal sapih anak, dan tanggal perkawinan anak. Selain itu dapat memprediksi kondisi induk seperti: awal dan akhir masa laktasi, awal dan akhir masa kering, perkiraan jumlah anak, dan jumlah susu yang diproduksi. Isian prediksi dilakukan melalui perhitungan rumus-rumus dengan mengacu pada pedoman beternak Kambing Etawa.

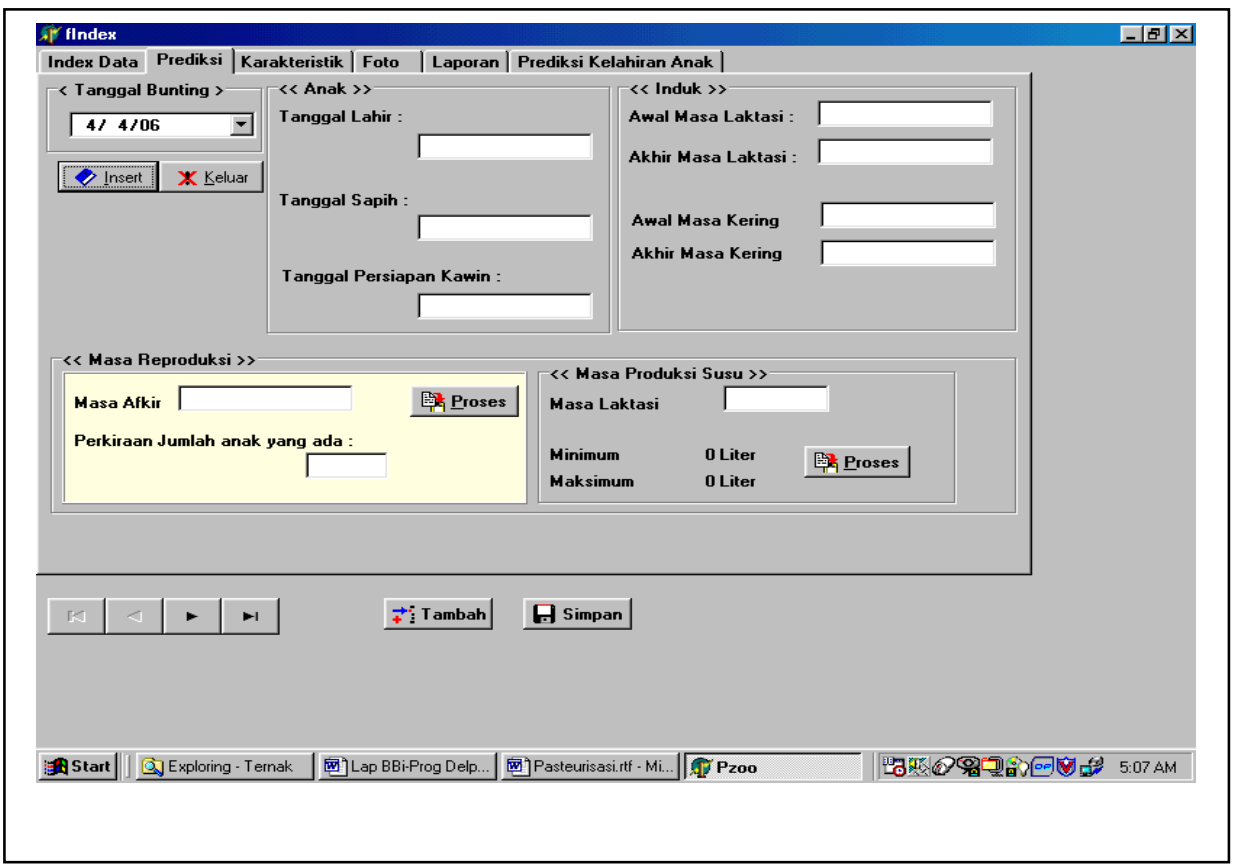

Gambar 3. Tampilan Menu Bar Prediksi yang belum terisi

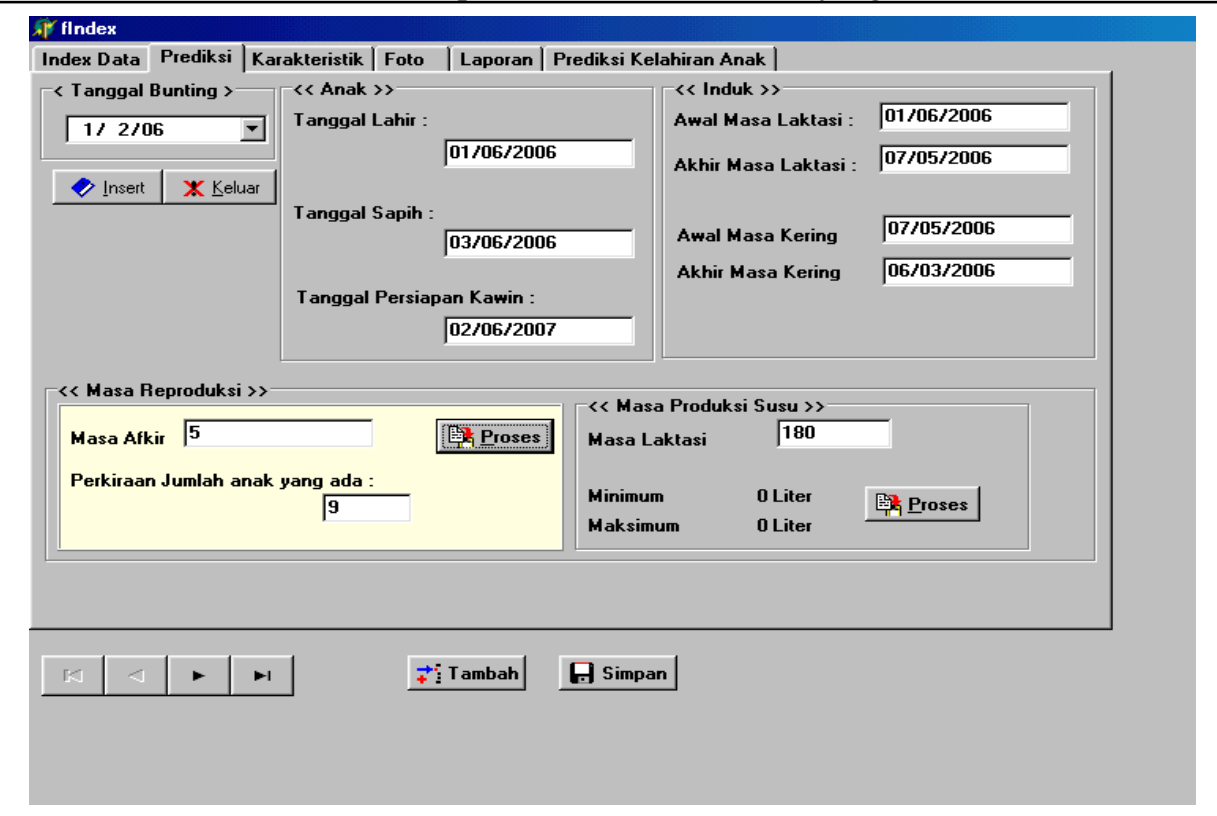




\section{Karakteristik}

Menu bar Karakteristik menampilkan isian tentang warna bulu, tinggi dan panjang bandan, dan tanduk. Pengisian dilakukan secara manual melalui papan ketik dan setelah melakukan pengisian data harus disimpan dengan cara mengklik bar simpan.

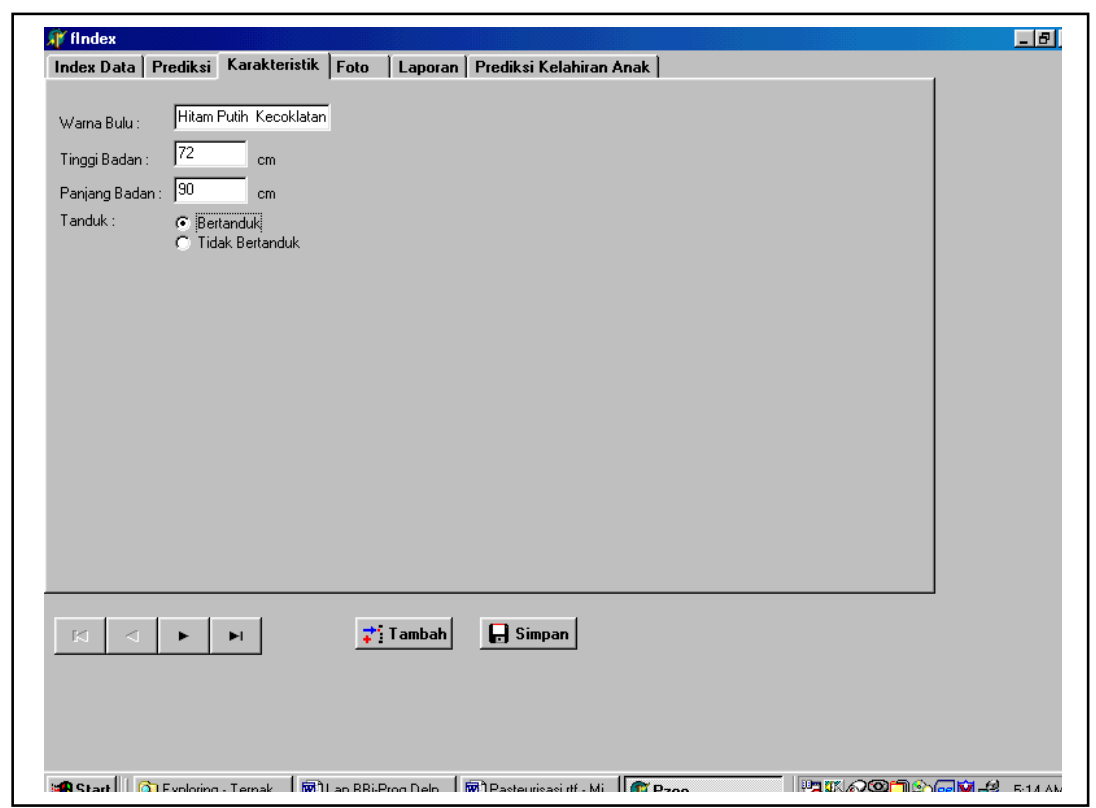

Gambar 5. Tampilan Menu Bar Karakteristik

Foto

Menu bar Foto menampilkan foto kambing yang datanya sudah terisikan. Hal ini dilakukan dengan cara memasukkan data foto kambing kedalam file program ini dan cara menampilkan kedalam program ini dilakukan dengan cara mengklik bar Cari Foto, kemudian cari foto yang sesuai dengan data yang dimasukkan, dan kemudian simpan.

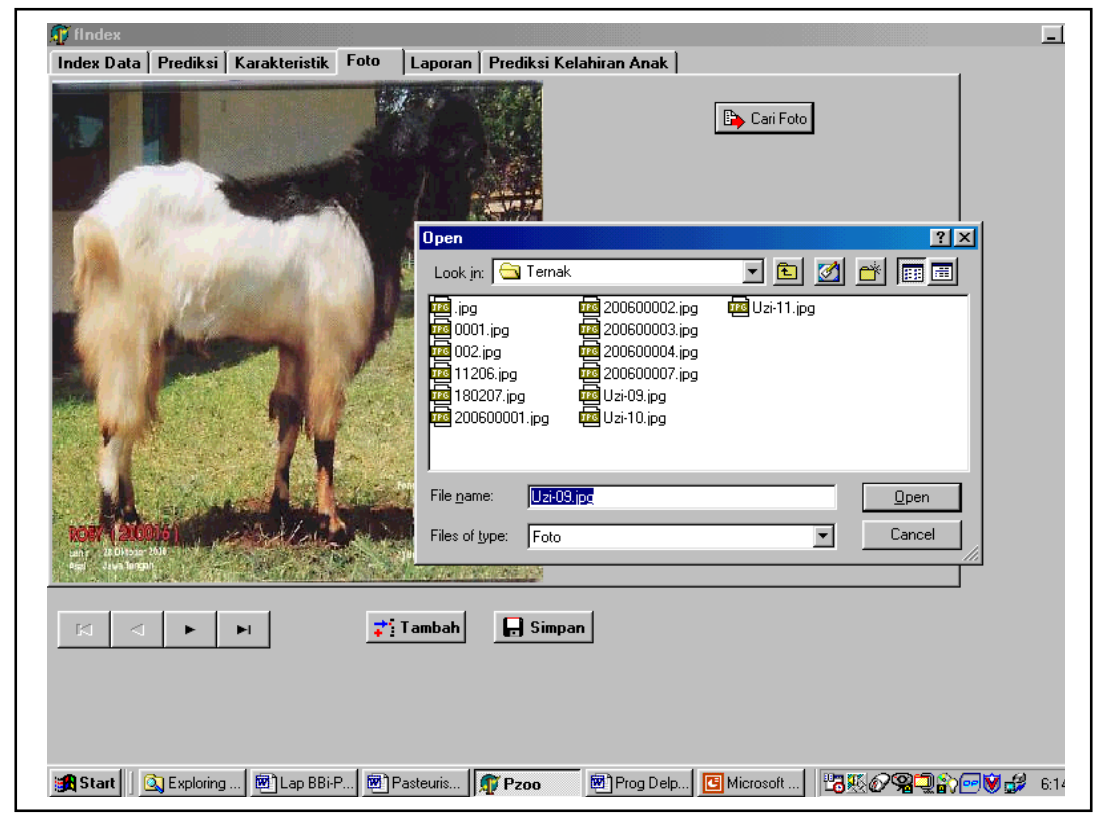

Gambar 6. Tampilan Menu Bar Foto 


\section{Laporan}

Menu bar Laporan menampilkan laporan data yang sudah terisi kedalam program dan dapat ditampilkan dalam bentuk Print Preview dan Print Kertas

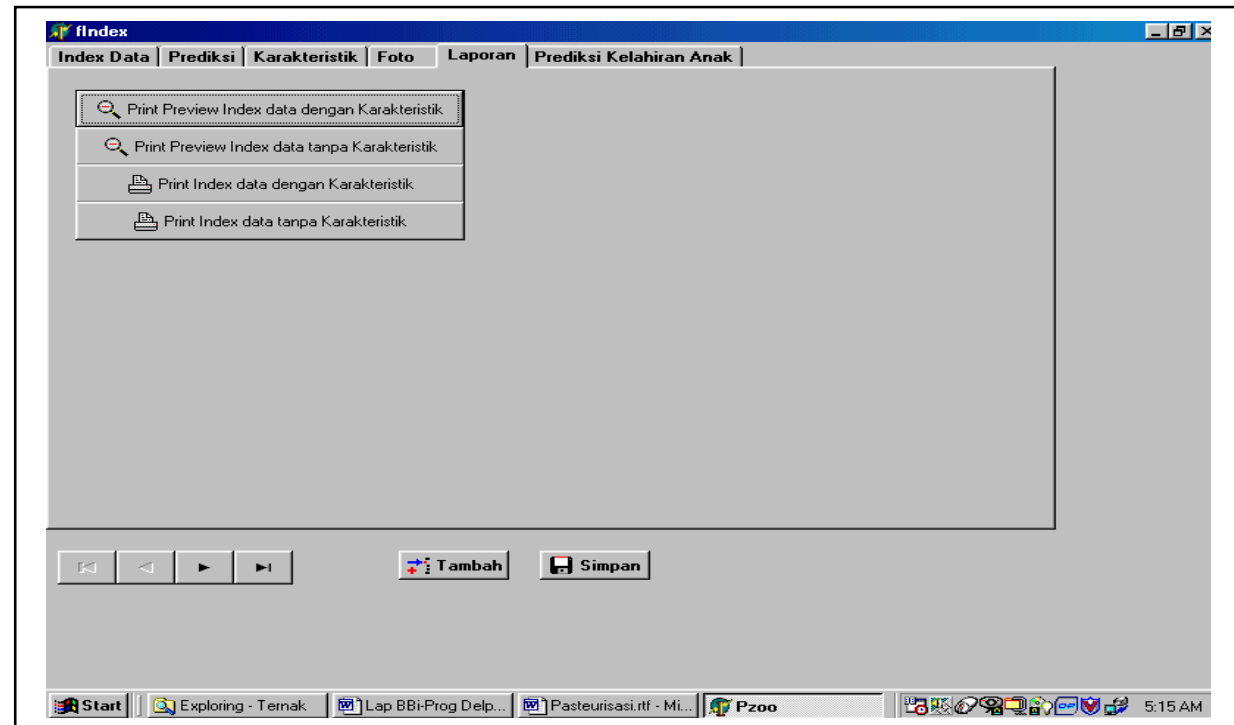

Gambar 7. Tampilan Menu Bar Laporan

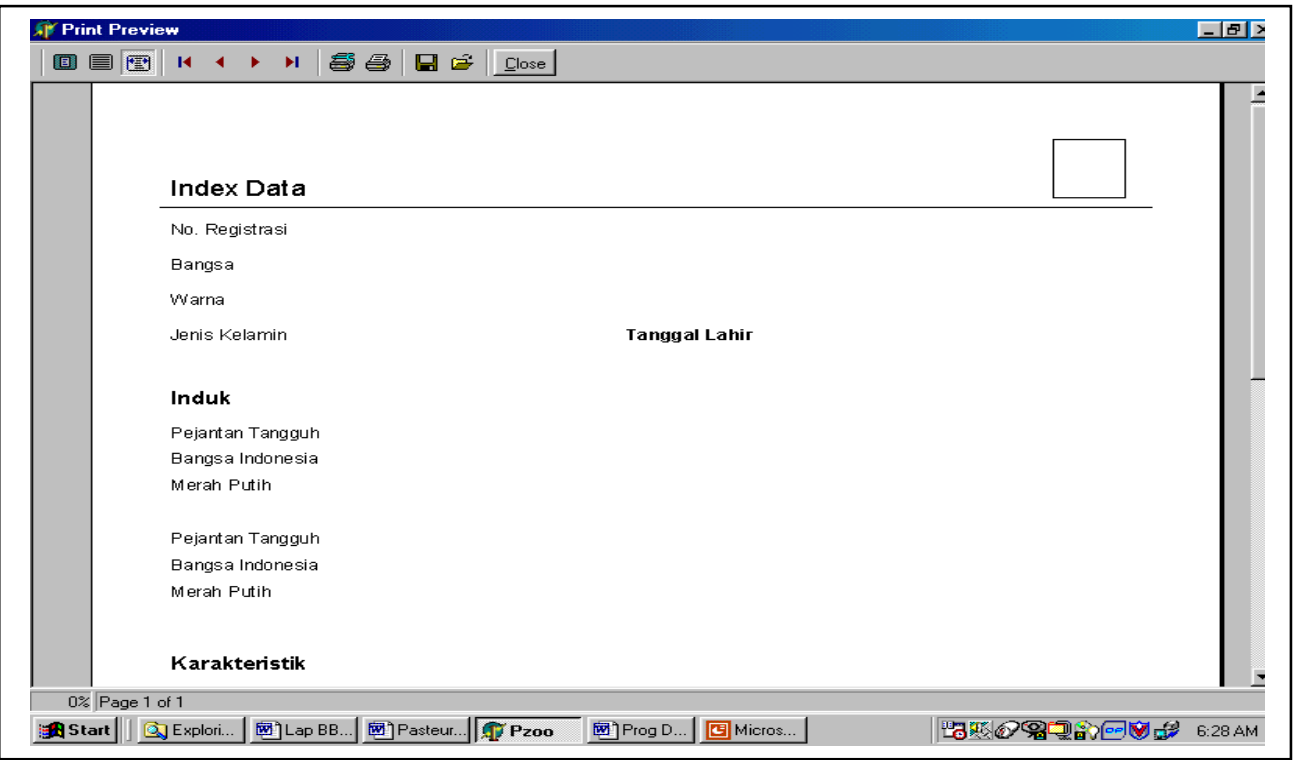

Gambar 8. Tampilan Menu Bar Laporan Print Preview

Prediksi Kelahiran

Menu bar Prediksi Kelahiran ini akan menampilkan jumlah anak yang lahir dengan cara memasukkan data Lama Masa Beranak, dan dengan perhitungan rumus maka jumlah anak yang akan dilahirkan akan terprediksi. 


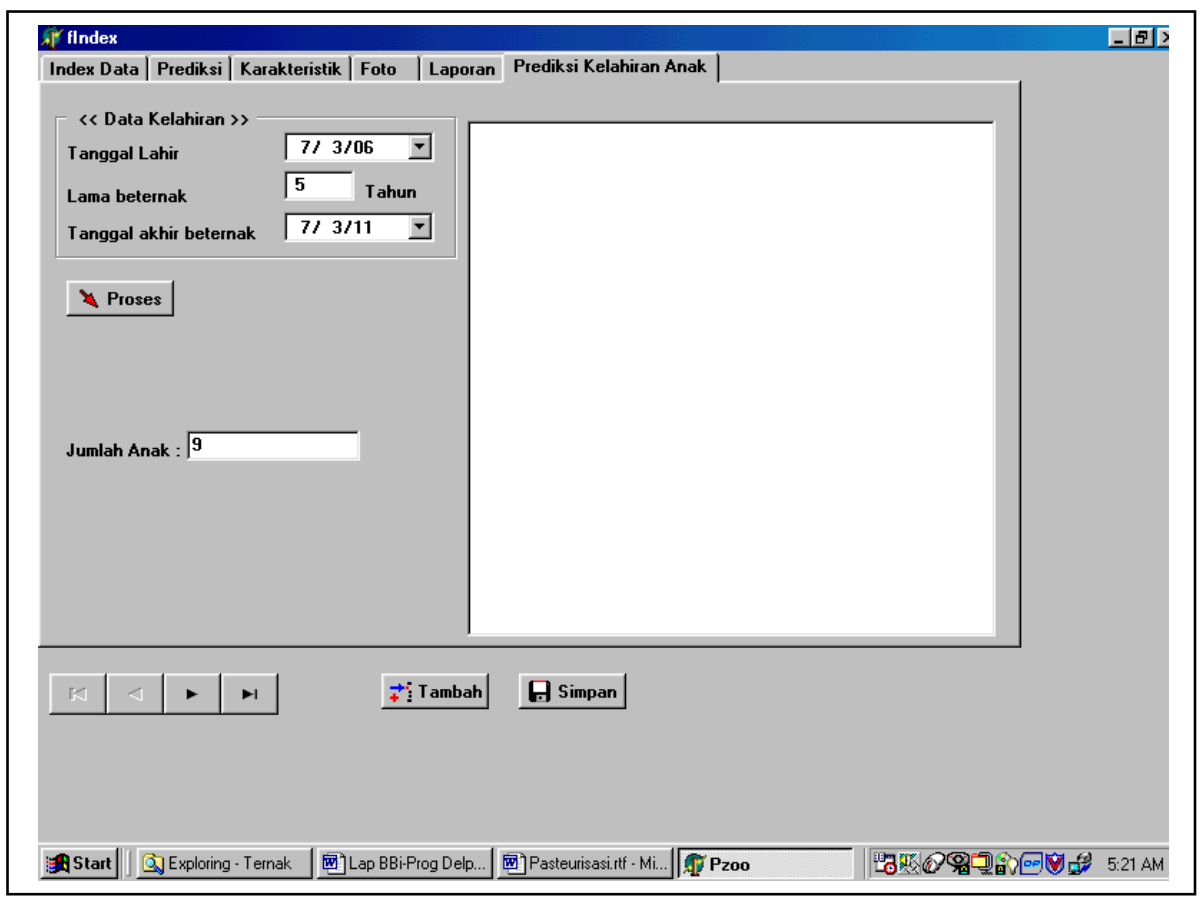

Gambar 9. Tampilan Menu Bar Prediksi Kelahiran

\section{KESIMPULAN DAN SARAN}

\section{Kesimpulan}

Dari hasil penelitian pembuatan kalender reproduksi kambing Etawa dengan Aplikasi program Delphi dapat disimpulkan bahwa:

a. Kalender Reproduksi dengan Delphi lebih Aplikatif

b. Aktivitas Petemak lebih terprogram, tepat waktu dan tepat kegiatan dalam pemeliharaan ternaknya. c. Memberikan pedoman bagi peternak kambing dalam memaksimalkan produktifitas ternaknya supaya dapat beranak tiga kali dalam dua tahun.

Saran

Untuk lebih memaksimalkan fungsi kalender reproduksi ini dan juga lebih menarik maka perlu ditambahkan grafik produksi anak dan susu dalam bentuk grafik. 


\section{DAFTAR PUSTAKA}

Devendra. C and G.B. McLeroy. 1987. Goat and Sheep Production in the Tropics. Longman Singapore Publishing Pte. Ltd. Singapore.

Devendra. C. and M. Burns. 1983. Goat Production in the Tropics. Commomwealth Agricultural. Bureaux.

Mishra, R.K., A.E. Nivsakar, and C.L. Arora. 1979. A note on the Analysis of Gestation Length in Sirohi Goats. Indian Journal of Animal Sciences 49 (11) 967968.
Otchere, E.O. and M.C. Nimo. 1978. Observations of the Reproductive Behaviour in the West African Dwarf Gooat. Ghana Journal of Agricultural Science 8 (3) 187-190.

Bolton, W. 1996. MECHATRONICS; Delphi, Longman Group Limited, Produced through longman Malyasia.

Kadir A. 2000. Dasar-Dasar Pemrograman Delphi. Penerbit ANDI Yogyakarta. Yogyakarta.

Sulasno, 1991, Beternak Kambing, Satya Wacana, Semarang. 